\title{
Increasing Online Purchasing: A Study Of Web Assurance And Web Insurance
}

C. Shane Warrick, Southern Arkansas University, USA

Terrye A. Stinson, Southern Arkansas University, USA

\begin{abstract}
Improving customer confidence is an important consideration, and potentially necessary ingredient, for increasing growth in electronic commerce. More than 1.2 billion people are internet users and, of that number, more than 215 million internet users live in the United States (Miniwatts Marketing Group 2008). Internet use in the United States, in fact, is second only to internet use in China (Barboza 2008). In its most recent study, the National Retail Federation (2008) estimated that U.S. online retail sales are approaching \$204 billion. Past studies identified issues associated with customer concerns in online transactions, and various forms of web assurance and web insurance have emerged as commercial mechanisms to ease these concerns and promote growth in ecommerce. Both mechanisms require strategic controls by a company developing its ecommerce information system. This paper continues the stream of research aimed at understanding how consumers view online purchasing with a focus on internet users in the United States. Results indicate that participants increase purchase intentions from vendors with either web assurance or web insurance, but that participants are indifferent regarding the choice of web assurance or web insurance. Recognizing these benefits, vendors should design strong controls within ecommerce information systems that support acquisition of either web assurance or web insurance that validate system security.
\end{abstract}

Keywords: Web assurance, web assurance seals, assurance and insurance concepts, online purchasing intention, consumer trust

\section{INTRODUCTION} mproving customer confidence is an important consideration, and potentially necessary ingredient, for
increasing growth in electronic commerce. More than 1.2 billion people are internet users and, of that
number, more than 215 million internet users live in the United States (Miniwatts Marketing Group 2008). Internet use in the United States, in fact, is second only to internet use in China (Barboza 2008). In its most recent study, the National Retail Federation (2008) estimated that U.S. online retail sales are approaching \$204 billion. With increased focus on internet sales, both business and academia are interested in understanding consumer perceptions about online purchases and in improving consumer actions toward making online purchases (Boo, Low, Soh, and Lim 2007 and Nikitkov 2006).

As internet sales increase, there is also an increase in the volume of personal information passing through the internet. Safety in handling this personal information, which includes credit card details and banking information, is an important issue for consumers and vendors. Both consumers and vendors face risks in internet transactions, and these risks must be minimized for efficient commerce. In recent years, two mechanisms have emerged to address these risks - web assurance and internet liability insurance. Web assurance is the ability to display a symbol that identifies the vendor as having passed an audit of its e-commerce process that was based on specific e-commerce standards. Web insurance is a purchased policy of the vendor that allows its customers to be compensated for damages in the event of a loss related to the e-commerce transaction. Both mechanisms require strategic controls by a company developing its ecommerce information system. Both mechanisms are intended to aid consumers in understanding that a vendor has internet security procedures; thus offering a "trust" to consumers 
by protecting their personal information. Increased trust, thereby, should increase online purchases (McKnight, Choudhury, and Kacmar 2002).

In recent years, a number of web assurance options have emerged. One familiar web assurance is the VeriSign seal. On its website, VeriSign claims to be one of the largest providers of internet infrastructure services, providing internet routing, security, and telecommunication services and protecting all forms of data from vandalism or theft. The company protects over one million web servers with digital certificates, including 93 percent of the Fortune 500 sites. (See www.verisign.com.) WebTrust and SysTrust, a joint venture between the American Institute of Certified Public Accountants (AICPA) and the Canadian Institute of Chartered Accountants (CICA), and TRUSTe are other familiar web assurances. (See www.techinsurance.com and www.truste.com.)

Internet liability insurance (web insurance) is one of the newest types of business insurance. Firms such as the Chubb Group of Insurance Companies (www.chubb.com) and Insuretrust (www.insuretrust.com) advertise on the internet as providers of insurance, protecting against e-theft and e-vandalism, and as experts in risk management for cyber liability.

Prior research by Boo et al. (2007) studied consumer views related to internet purchases in China, which has the world's largest internet market. In their study, Boo et al. compared the effect of web assurance and web insurance on consumer purchase intentions and consumer trust. Modifying Boo's research model, the current study seeks to continue the stream of research aimed at understanding how consumers view online purchasing with a focus on internet users in the United States. The following sections summarize related literature, methodology, and results of the current study.

\section{LITERATURE REVIEW}

As commerce on the internet increased, research emerged about the complex nature of online purchasing. Studies showed that conservative consumers and possibly avid internet users struggle with online purchasing because of fears and concerns associated with the transmitting of personal information (Odom et al. 2002; Cranor et al. 1999; and Culnan 2000). Odom, Kumar, and Saunders (2002) describe the primary concerns of consumers security in the transaction, privacy of the provided information, legitimacy of the business, price of the product, and customer service. These issues are risks that e-vendors must overcome to encourage consumers to purchase products. Mitigating those risks will instill "trust" in the consumer for the appropriateness of making the online purchase. McKnight, Choudhury, and Kacmar (2002) evaluate how e-vendors can mitigate risks and propose a trust building model. According to McKnight et al., trust from a consumer toward a vendor has two components: trusting beliefs (the vendor is competent) and trusting intentions (a willingness to be vulnerable). These components can be controlled by the e-vendor with three antecedents: web assurance (providing a sense of safety and security to the customer), site quality, and site reputation.

Based on McKnight's research, Nikitkov (2006) used online sales transactions to evaluate the trust building model with web assurance seals. Nikitkov's archival method tested purchase behavior at online sites, such as eBay, and found that web assurance seals lead to increased consumer purchases, an indication of increased trust for transacting. Mauldin and Arunachalam (2002) and Pennington, Wilcox and Grover (2003), however, found that trust and increased purchase intentions are not associated with web assurance.

Boo, Low, Soh, and Lim (2007) compared web assurance and web insurance by studying consumers' internet purchasing intentions. Their study asked 360 university students to participate in an experiment related to the internet purchase of carpet. It was conducted at the Nanyang Technological University in Singapore with nonU.S. participants. Results indicate that web assurance and web insurance are effective in increasing consumer online purchase behavior and that consumers do not have a preference between web assurance or web insurance.

\section{METHODOLOGY}

The current study seeks to continue the stream of research on consumers' perceptions related to online purchasing. This study is a replication of Boo et al. (2007). However, the current study triangulates the methods 
used by Boo et al. Other research by Flick (1992) and Hunton, McEwen, and Wier (2002) notes that triangulation, the use of differing methods and variables in research, provides better understanding of the phenomena being studied. The need for replicating the Boo et al. study is two fold. Their study was carried out with non-U.S. citizens, so information is needed on the generalization of their study findings. Additionally, the Boo et al. study used a between-subject design experiment to evaluate online purchase intentions; this method may not capture the true online purchase experience where multiple e-vendors offer competing products. Harsha and Knapp (1990) note that within-subject designs are appropriate when a decision maker faces multiple conditions, which can affect the final decision being made. Accordingly, the current study uses a within-subject design and includes participants from a regional university in the United States.

The two hypotheses developed for the current study test the findings of the Boo et al. research. Their study found that web assurance and web insurance increase the purchase intentions of consumers. Additionally, they found that consumers considered web assurance and web insurance to offer equal "trust" for increasing online purchase intentions.

H1: Consumer intentions to purchase from an online vendor offering web assurance or web insurance will be greater than that of a vendor not offering either of those features.

H2: Consumers will have greater confidence in online purchases from a vendor offering web assurance or web insurance than that of a vendor not offering either of those features.

\section{Experiment and Survey Design}

A within-subject design experiment was created to evaluate the perceptions of individuals on internet purchasing habits related to the web assurance and web insurance issue. The experiment was designed similar to the experiment used in Boo et al. (2007). However, the research instrument in the current study was modified to accommodate a within-subject design verse the between-subject design offered in Boo et al. (2007). The instrument asks the respondents to evaluate the purchase of a cruise vacation package to be given to two of their family members. The base facts of the case offer details on how an internet search has identified three potential e-vendors and that each offers an identical cruise vacation package for the price of $\$ 1,000$. The e-vendors' vacation packages are identical to a package offered by a local travel agent, but the e-vendors' prices are 10 percent lower. The respondents are told that e-vendors operate exclusively online and that e-vendors require personal and credit card information that must be given to purchase a vacation package.

The manipulation of the experiment is related to the security measures offered by each e-vendor. Each evendor is identified by name and its information security policy is disclosed. The control e-vendor is Cruise Vacations, which offers to sell the vacation package but does not provide information about its security practices. The second vendor, Dream Cruises, offers web assurance as a security practice. The third vendor, Open Sea Vacations, offers web insurance as a security practice. The survey asks each respondent the following two questions about each e-vendor:

- How likely are you in purchasing the vacation package online from "e-vendor name" on a scale ranging from $0 \%$ (will definitely not purchase) to $100 \%$ (will definitely purchase)?

- How confident are you in making a purchase online from "e-vendor name" on a scale ranging from $0 \%$ (not confident at all) to $100 \%$ (absolutely confident)?

To decrease the possible demand effects from using the within-subject design, three versions of the instrument were created (Harsha and Knapp 1990). The order in which each e-vendor's treatment is presented shifted from first to second to third. A manipulation check question is offered to determine if the respondents noted the difference between the e-vendor treatment conditions. The manipulation question asked each respondent:

- What features separated the e-commerce vendors? Circle all that apply. Web Assurance, Web Insurance, Cruise Location. 


\section{Testing Method}

To evaluate the within-subject design experiment for statistical significance, the current study uses the Friedman two-way analysis of variance by ranks test. The Friedman test is the nonparametric counterpart to the repeated measures analysis of variance. Data presented in the study are not expected to meet the assumptions of the parametric test. The normal distribution and equal variance assumptions in parametric tests are not required for the nonparametric test. Additionally, small sample sizes can be evaluated with the Friedman test. The Friedman test is based on the Chi-square distribution for testing the significance of an observed difference between $\mathrm{k}$ matched samples ( $k=3$ in the current study). However, the test does not identify which pair or pairs of k-matched samples are different. Therefore, once the overall significance of the model is established, a post hoc multiple comparison test is needed to identify which group pair(s) is different (Siegel and Castellan 1998). Similar to the repeated measure ANOVA, the Friedman ANOVA is appropriate to the current study because the respondents evaluate multiple treatment conditions.

\section{Participants}

The experiment was carried out at a small regional public university that offers an undergraduate business degree program. It was administered to fifty-seven participants in various accounting and management classes in the spring 2008. Table 1 provides details on the demographics of the participants. Responses to the demographic questions were incomplete on five surveys, resulting in usable demographic data on fifty-two participants. As shown in Table 1, slightly over half of the participants are males. Most participants (65\%) are white; the second largest ethnic group is African-American (23\%). Most participants (62\%) are in the 21-24 age group; 17 percent are over 30 . Over 90 percent of the respondents are juniors and seniors.

Table 1

Demographic Distribution of Participants

\begin{tabular}{|l|l|c|c|}
\hline \multicolumn{2}{|l|}{} & Frequency & Percentage \\
\hline Gender & Male & 29 & 56 \\
\hline & Female & 23 & 84 \\
\hline Ethnicity & Asian & 4 & 23 \\
\hline & African-American & 12 & 2 \\
\hline & Hispanic & 1 & 65 \\
\hline & White & 34 & 2 \\
\hline Age & Not Listed & 1 & 17 \\
\hline & $18-20$ Years & 9 & 62 \\
\hline & $21-24$ Years & 32 & 4 \\
\hline & $25-30$ Years & 2 & 17 \\
\hline Major & Over 30 Years & 9 & 46 \\
\hline & Accounting/Finance & 24 & 42 \\
\hline & Management/Marketing & 22 & 8 \\
\hline & MIS & 4 & 4 \\
\hline Year & Not Listed & 2 & 9 \\
\hline & Freshman/Sophomore & 5 & 33 \\
\hline & Junior & 17 & 58 \\
\hline
\end{tabular}

\section{RESULTS}

Question one on the survey asked participants to indicate their likelihood of purchasing each vacation package, where the treatments included no security information, web assurance, or web insurance. Hypothesis one evaluates the purchase intention responses associated with each of the three treatment conditions using the withinsubject analysis design. Table 2 presents the results of the Friedman two-way analysis of variance test for H1, indicating that there is significant difference $(\mathrm{p}=.000)$ between the three treatments. 
A post hoc multiple comparison test was conducted to determine which pairs of matched samples are different. The multiple comparison tests compared each pair of matched samples for their responses. As shown in Table 3, results indicate a significant difference $(\mathrm{p}<.05)$ between web assurance versus the control condition of no security information and a significant difference $(\mathrm{p}<.05)$ between web insurance versus the control condition of no security information. This suggests that consumer intentions to purchase would be greater for e-vendors offering either web assurance or web insurance. Comparison of web assurance and web insurance, however, indicates no significant difference $(p>.10)$ between the two options. Given no difference between these treatments, participants are indifferent between these options, and either web assurance or web insurance will increase their purchase intentions.

Based on the results summarized in Tables 2 and 3, H1 is supported. These results agree with the finding of Boo et al. (2007).

Table 2

Friedman Two-way Analysis of Variance by Ranks

\begin{tabular}{|l|c|c|c|}
\hline & \multicolumn{2}{|c|}{ Purchase Intent Decision } & Mean \\
\hline Treatment & Frequency & & \\
\hline No security information & & 37.72 & 29.018 \\
\hline Web assurance & 57 & 61.58 & 27.809 \\
\hline Web insurance & 57 & 66.40 & 27.803 \\
\hline Treatment & 57 & Mean Rank & \\
\hline No security information & & 1.40 & \\
\hline Web assurance & & 2.11 & \\
\hline Web insurance & & & \\
\hline Chi-square Value & 39.719 & & \\
\hline P-value & .000 & & \\
\hline
\end{tabular}

Table 3

Multiple Comparison Test

\begin{tabular}{|l|c|c|c|c|}
\hline \multicolumn{1}{|c|}{ Treatment } & Mean Rank & $\begin{array}{c}\text { Absolute Value } \\
\text { Difference by Group }\end{array}$ & $\begin{array}{c}\text { Critical Value at } \\
\boldsymbol{\alpha}=. \mathbf{0 5}\end{array}$ & $\begin{array}{c}\text { Critical Value at } \\
\boldsymbol{\alpha}=. \mathbf{1 0}\end{array}$ \\
\hline No security information & 1.40 & & & \\
\hline Web assurance & 2.11 & & & \\
\hline Web insurance & 2.49 & & .448 & .397 \\
\hline $\begin{array}{l}\text { No security information } \\
\text { versus web assurance }\end{array}$ & & $1.40-2.11=.71$ & .448 & .397 \\
\hline $\begin{array}{l}\text { No security information } \\
\text { versus web insurance }\end{array}$ & & $1.40-2.49=1.09$ & .448 & .397 \\
\hline $\begin{array}{l}\text { Web assurance versus web } \\
\text { insurance }\end{array}$ & & $2.11-2.49=.38$ & & \\
\hline For signe & & & & \\
\hline
\end{tabular}

For significance at the alpha level, the absolute value difference must be greater than the critical value. The only nonsignificant grouping is web assurance versus web insurance.

Question two asked participants to indicate their level of confidence in making the online purchase. Hypothesis two evaluates the confidence level of the purchase intentions associated with each of the three treatment conditions. The results of the Friedman two-way analysis of variance test for $\mathrm{H} 2$ are found in Table 4, indicating a significant difference $(p<.000)$ in the purchase confidence between the three treatments. 
Table 4

Friedman Two-way Analysis of Variance by Ranks

\begin{tabular}{|l|c|c|c|}
\hline & \multicolumn{2}{|c|}{ Confidence Level in Purchase Decision } & Mean \\
\hline & Frequency & & Standard Deviation \\
\hline Treatment & & & 29.069 \\
\hline No security information & 57 & 64.12 & 26.978 \\
\hline Web assurance & 57 & 70.14 & 27.003 \\
\hline Web insurance & 57 & Mean Rank & \\
\hline Treatment & & 1.35 & \\
\hline No security information & & 2.15 & \\
\hline Web assurance & & 2.50 & \\
\hline Web insurance & & & \\
\hline Chi-square Value & 43.337 & & \\
\hline P-value & .000 & & \\
\hline
\end{tabular}

A post hoc multiple comparison test was conducted to determine which pairs of matched samples are different related to purchase confidence. As shown in Table 5, results indicate a significant difference $(\mathrm{p}<.05)$ between the participants' level of purchase confidence with web assurance versus the control condition of no security information and a significant difference $(\mathrm{p}<.05)$ between the participants' level of purchase confidence with web insurance versus the control condition of no security information. This suggests that consumer confidence to purchase would be greater for e-vendors offering either web assurance or web insurance. Comparison of web assurance and web insurance, however, indicates no significant difference $(\mathrm{p}>.10)$ between the two security options. Given no difference between these treatments, results indicate that participants are indifferent, and either web assurance or web insurance will increase the confidence level in their purchase decisions.

Table 5

Multiple Comparison Test

\begin{tabular}{|l|c|c|c|c|}
\hline \multicolumn{1}{|c|}{ Treatment } & Mean Rank & $\begin{array}{c}\text { Absolute Value } \\
\text { Difference by Group }\end{array}$ & $\begin{array}{c}\text { Critical Value at } \\
\boldsymbol{\alpha}=. \mathbf{0 5}\end{array}$ & $\begin{array}{c}\text { Critical Value at } \\
\boldsymbol{\alpha}=\mathbf{. 1 0}\end{array}$ \\
\hline No security information & 1.35 & & & \\
\hline Web assurance & 2.15 & & & \\
\hline Web insurance & 2.50 & & .448 & .397 \\
\hline $\begin{array}{l}\text { No security information } \\
\text { versus web assurance }\end{array}$ & & $1.35-2.15=.80$ & .448 & .397 \\
\hline $\begin{array}{l}\text { No security information } \\
\text { versus web insurance }\end{array}$ & & $1.35-2.50=1.15$ & .448 & .397 \\
\hline $\begin{array}{l}\text { Web assurance versus web } \\
\text { insurance }\end{array}$ & $2.15-2.50=.35$ & & \\
\hline For & & & & \\
\hline
\end{tabular}

For significance at the alpha level, the absolute value difference must be greater than the critical value. The only nonsignificant grouping is web assurance versus web insurance.

Based on the results summarized in Tables 4 and 5, H2 is supported. These results agree with the finding of Boo et al. (2007).

In providing analysis of the hypotheses, the experimental manipulation must be addressed. Fifty-seven individuals completed the experiment, but of those only twenty-six participants (46\%) answered the manipulation check question correctly. The low response rate for correctly answering the manipulation check in the instrument does not have a significant impact on the study. The results of the experimental analysis are the same when both successful and non-successful participants are considered in the evaluation. Therefore, all the participants are included in the analysis of the experimental treatment. 
In summary, findings of the current study supports the original findings of Boo, Lew, Soh, and Lim. Differences in the two studies add validity to the original findings and extend its application. The Boo et al. study included non-U.S. participants; the current study includes U.S. participants. Therefore, the generalization of the original research carries to multiple populations. The Boo et al. study used a between-subjects experiment design, while the current study used a within-subject design. Therefore, the generalization of the original research carries over a different statistical method.

\section{CONCLUSION}

The study provides a replication of the Boo et al. (2007) research study. Respondents to a within-subject design experiment are offered three treatment conditions in which to consider their online purchase intentions and their confidence in e-vendors offering web assurance, web insurance, or neither feature. Each hypothesis was supported, thus leading to the conclusion that web assurance and web insurance do increase purchase intentions and confidence in e-commerce vendors. Additionally, the participants were indifferent regarding the option of the vendor providing web assurance or web insurance.

The findings of the study are important to the information system literature for several reasons and offer support for the generalization of the Boo et al. study. Therefore, there is additional confirmation for the validity of the findings that web assurance and web insurance encourage trust in online purchase decisions. Since consumers respond positively to web assurance and web insurance, vendors should carefully consider the benefits of designing ecommerce information systems that support these trust mechanisms. Incorporating web assurance or web insurance begins with strategic decisions related to the information system and requires strong control features that validate the system security.

The current study has limitations that could affect the results of the study. The small sample size, for one, could affect the results; however, the chosen nonparametric test used in evaluating the study accommodates such sample sizes. The low success rate on the manipulation check could affect results; this was considered appropriately but may indicate the need for addition analysis in future research. Furthermore, actual behavior of individuals might be different than that of the perceptions given in the experimental study.

Future research should consider archival studies comparing web assurance and web insurance impacts on purchases. This could be carried out similarly to Nikitkov (2006). Future research could also evaluate online purchasing from e-vendors with web assurance or web insurance compared to purchasing from traditional stores.

\section{AUTHOR INFORMATION}

C. Shane Warrick, MBA, CPA, is a member of the Southern Arkansas University accounting faculty. He earned his BBA from Southern Arkansas University and MBA from the University of Arkansas at Little Rock; he is a doctoral student at Jackson State University. Warrick has published in the Journal of Business, Industry, and Economics; Journal of Business Administration Online; and College Teaching Methods and Styles Journal. Previously, he worked for KPMG, Murphy Oil Corporation, and International Paper Company. He is a member of the Arkansas Society of CPAs and an educational associate of the Association of Certified Fraud Examiners.

Terrye A. Stinson, DBA, CPA, is the L.J. Blanchard Professor of Accounting at Southern Arkansas University. She earned her MBA and DBA from Louisiana Tech University. Her research interests include financial accounting and strategies for effective teaching. She has published in the Journal of College Teaching and Learning; Journal of Learning in Higher Education; Review of Business Information Systems; CLEAR Exam Review; and Ethics and Critical Thinking Journal. Stinson is a member of the AICPA and Arkansas Society of CPAs. She currently serves on the Arkansas State Board of Public Accountancy and the Arkansas Society's Student Education Fund Board. 


\section{REFERENCES}

1. Barboza, D. (July 26, 2008) China surpasses U.S. in number of internet users, New York Times, 3

2. Boo, E., K. Low, X. Soh, \& M. Lim (2007) Assurance versus insurance: a study of consumer receptiveness in an e-commerce setting, Accounting Horizons 21 (4): 331-350

3. Cranor, L., J. Reagle, \& M. Ackerman (1999) Beyond concern: understanding net users' attitudes about online privacy, AT\&T Labs-Research Technical Report. Available at www.ftc.gov/bcp/icpw/comments/attlabs.htm (Accessed on May 3, 2008)

4. Culnan, M. (2000) Protecting privacy online: Is self-regulation working? Journal of Public Policy and Marketing 19 (1): 20-26

5. Flick, U. (1992) Triangulation revisited: strategy of validation or alternative? Journal of the Theory of Social Behaviour 22 (2): 175-197

6. Harsha, P. \& M. Knapp (1990) The use of within- and between-subjects experimental designs in behavioral accounting research: a methodological note, Behavioral Research in Accounting (2): 50-62

7. Hunton, J., R. McEwen, \& B. Wier (2002) The reaction of financial analysts to enterprise resource planning (erp) implementation plans, Journal of Information Systems 16 (1): 31-40

8. Mauldin, E. \& V. Arunachalam (2002) An experimental examination of alternative forms of web assurance for business-to-consumer e-commerce, Journal of Information Systems 16 (1): 33-54

9. McKnight, D., V. Choudhury, \& C. Kacmar (2002) The impact of initial consumer trust on intentions to transact with a website: A trust building model, Journal of Strategic Information Systems 11 (3-4): 297-323

10. Miniwatts Marketing Group (2008) Internet usage statistics - The big picture, Available at www.internetworldstats.com/stats.htm (Accessed on May 2, 2008)

11. National Retail Federation (2008) Online Sales to Climb Despite Struggling Economy, Available at http://www.nrf.com/modules.php?name=News\&op=viewlive\&sp_id=499 (Accessed on May 3, 2008)

12. Nikitkov, A. (2006) Information assurance seals: How they impact consumer purchasing behavior, Journal of Information Systems 20 (1): 1-17

13. Odom, M., A. Kumar, \& L. Saunders (2002) Web assurance seals: How and why they influence consumers' decisions, Journal of Information Systems 16 (2): 231-250

14. Pennington, R., H. Wilcox, \& V. Grover (2003) The role of system trust in business-to-consumer transactions, Journal of Management Information Systems 20 (2): 197-226

15. Siegel, S. \& N. Castellan Jr. (1988) Nonparametric Statistics for the Behavioral Sciences 2e. McGraw Hill.

16. $\quad$ www.chubb.com

17. www.insuretrust.com

18. $\quad$ www.techinsurance.com

19. www.truste.com

20. www.verisign.com 